\title{
PENGARUH PELAYANAN TENAGA ADMINISTRASI DAN KUALITAS KERJA TENAGA MEDIS TERHADAP KEPUASAN PASIEN BPJS YANG DIMODERASI OLEH KEPERCAYAAN PASIEN
}

\author{
Lukiyana ${ }^{1}$, Arsinta $^{2}$ \\ Fakultas Ekonomi dan Bisnis, Universitas 17 Agustus 1945 Jakarta
}

\begin{abstract}
This study aims to analyze the effect of service quality on patient satisfaction BPJS users, analyze the service of administrative personnel to satisfaction, analyze the influence of the quality of medical workfor the user satisfaction BPJS.Kualitas service is a form of service provided by the service provider, in this case the hospital, with the quality of this service will impact on patient satisfaction. Research location at MH.Thamrin Hospital by taking samples of 100 patients using BPJS questionnaire. In this research using sampling technique using probabily sampling and data analysis method used in this research is PLS (Partial Least Square) 3.0. The result of this research is that the service of administration personnel is significant to the satisfaction of BPJS patient, the quality of the work of medical personnel is significant to the satisfaction of BPJS patient, the patient's trust is significant to the satisfaction of BPJS patient.
\end{abstract}

\begin{abstract}
ABSTRAK
Penelitian ini bertujuanuntuk menganalisis pengaruh kualitas pelayanan terhadap kepuasan pasien pengguna BPJS, menganalisis pelayanan tenaga administrasi terhadap kepuasan, menganalisis pengaruh kualitas tenaga kerja medis terhadap kepuasan pengguna BPJS.Kualitas pelayanan merupakan suatu bentuk pelayanan yang diberikan pihak penyedia layanan, dalam hal ini rumah sakit, dengan kualitas pelayanan ini akan berdampak pada kepuasan pasien. Lokasi penelitian di Rumah Sakit MH.Thamrin dengan mengambil sampel 100 pasien pengguna BPJS menggunakan kuesioner. Dalam penelitian ini menggunakan teknik pengambilan sampel menggunakan probabily sampling dan metode analisis data yang digunakan dalam penelitian ini adalah PLS (Partial Least Square) 3.0. Hasil dari penelitian ini bahwa pelayanan tenaga administrasi signifikan terhadap kepuasan pasien BPJS, kualitas kerja tenaga medis signifikan terhadap kepuasan pasien BPJS , kepercayaan pasien signifikan terhadap kepuasan pasien BPJS.
\end{abstract}

Kata Kunci :Kepuasan Pasien BPJS, Kepercayaan PasienPelayanan Tenaga Administrasi, Kualitas Kerja Tenaga Medis

\section{PENDAHULUAN}

Program baru pemerintah pusat lewat Kementerian Kesehatan (Kemenkes) memberikan jaminan sosial kesehatan bagi masyarakat melalui Badan Penyelenggara Jaminan Sosial Kesehatan (BPJS), Program BPJS kesehatan masih lemah sosialisasi kepada masyarakat. Masyarakat belum memahami betul soal alur pengurusan kartu BPJS kesehatan. Akibatnya, pihak penyelenggara BPJS dihadapkan dengan berbagai protes dan komentar miring keluarga pasien yang membutuhkan pelayanan tetapi tidak memiliki kartu Jamkesmas (Duta, 2014). Masalah yang sering di jumpai pada pengguna BPJS adalah keluhan asuhan keperawatan yang diberikan dan pengobatan yang di berikan tidak semuanya dapat di berikan secara gratis. Pelayanan yang diberikan cenderung tidak memenuhi kepuasan pasien (Jugnis BPJS, 2014). Tahun 2014 di Indonesia data pengguna BPJS mencapai 116.122.065 jiwa. Indonesia 400 kabupaten / kota di Indonesia, sudah ada 143 kabupaten yang telah berintegrasi masuk ke jaminan kesehatan nasional. Dua unsur penting dalam upaya peningkatan pelayanan kesehatan adalah tingkat kepuasan pasien sebagai pengguna jasa dan pemenuhan standar pelayanan medis yang telah ditetapkan oleh pemerintah. 


\section{LAPORAN KINERJA PENGELOLAAN PROGRAM BPJS KESEHATAN BPJS Kesehatan \\ Badan Penyelenggara Jaminan Sosial}

PESERTA BPJS KESEHATAN S/D 31 DESEMBER 2014\& 2015

TOTAL 133.423.653 JIWA

\begin{tabular}{|l|l|l|}
\hline Peserta BPJS & Tahun 2014 & Tahun 2015 \\
\hline Bukan Pekerja (BP) & 4.876 .416 & 133.423 .653 \\
\hline Pekerja Bukan Penerima Upah (PBPU) & 9.052 .859 & 141.102 .294 \\
\hline Pekerja Penerima Upah (PPU) & 24.327 .149 & 147.675 .544 \\
\hline Penerima Bantuan Iuran & 86.400 .000 & 152.322 .190 \\
\hline JAMKESDA DAN PJKMU ASKES & 8.767 .229 & 156.790 .287 \\
\hline
\end{tabular}

Fasilitas Kesehatan Tingkat Pertama (Puskesmas/Dokter PraktekPerorangan/Klinik Pratama)

\begin{tabular}{|l|l|l|}
\hline Tahun & Total FKTP & $\begin{array}{l}\text { Dokter / Dokter Gigi Praktek } \\
\text { Perorangan/ Klinik Pratama })\end{array}$ \\
\hline Des 2013 & 3,606 & 12,993 \\
\hline Mar 2014 & 5,343 & 16,430 \\
\hline Jun 2014 & 5,748 & 16,831 \\
\hline Sep 2014 & 6,577 & 17,681 \\
\hline Des 2014 & 7,317 & 18,450 \\
\hline 01 Jan 2015 & & 18,437 \\
\hline s.d 31 Mar 2015 & & 19,012 \\
\hline s.d 30 Jun 2015 & & 19,436 \\
\hline s.d 30 Sep 2015 & & 19.657 \\
\hline s.d 31 Des 2015 & & 19,969 \\
\hline
\end{tabular}


Fasilitas Kesehatan Rujukan Tingkat Lanjutan ( Rumah Sakit)

\begin{tabular}{|l|l|l|}
\hline Tahun & RS. Pemerintah & RS. Swasta \\
\hline Des 2013 & 1109 & 346 \\
\hline Mar 2014 & 1441 & 557 \\
\hline Jun 2014 & 1551 & 586 \\
\hline Sep 2014 & 1592 & 617 \\
\hline Des 2014 & 1681 & 652 \\
\hline 01 Jan 2015 & 919 & 662 \\
\hline s.d 31 Mar 2015 & 837 & 902 \\
\hline s.d 30 Jun 2015 & 839 & 944 \\
\hline s.d 30 Sep 2015 & 854 & 961 \\
\hline s.d 31 Des 2015 & 857 & 990 \\
\hline
\end{tabular}

Kepuasan Pelanggan Tahun 2014 81\% Indeks Kualitas Layanan Fasilitas Kesehatan 78\%Kepuasan Pelanggan Tahun 2015 78,90\% (Sumber : BPJS Kesehatan)Kepuasan pasien merupakan satu elemen yang penting dalam mengevaluasi kualitas layanan dengan mengukur sejauh mana respon pasien setelah menerima jasa. Kualitas pelayanan yang baik di dalam rumah sakit, akan menciptakan kepuasan bagi para pasien. Pada tahun 2015, hasil kajian indeks kualitas pelayanan fasilitas kesehatan BPJS Kesehatan menunjukkan pencapaian kualitas input sebesar $79 \%$, proses $65 \%$, dan outcome $76 \%$, dengan rata-rata sebesar 73\%. Kajian tersebut dilakukan di 49 kabupaten/kota dari 14 provinsi yang dipilih secara acak melalui survei dan wawancara kepada 533 orang pengelola Puskesmas, Dokter Praktek Perorangan, Klinik Pratama, dan rumah sakit. Penelitian yang dilakukan Widiasih(2014) tentang persepsi masyarakat terhadap pelayanan BPJS di RSI.Kendal. penelitian menunjukan dari 215 responden,
$45,1 \%$ atau sebanyak 97 orang mempunyai persepsi baik dan $15,8 \%$ atau 34 orang persepsi sangat baik dan terakhir $39,1 \%$ atau 84 orang persepsi tidak baik.

Sesuai dengan rumusan masalah yang telah dikemukakan, maka penelitian ini dimaksudkan:

1. Untuk menganalisis seberapa besar pelayanan tenaga administrasi terhadap kepuasan pasien BPJS ?

2. Untuk menganalisis seberapa besar pengaruh kualitas tenaga medis terhadap kepuasan pasien BPJS?

3. Untuk menganalisis seberapa besar kepercayaan pasien berpengaruh terhadap kepuasan pasien BPJS?

4. Untuk menganalisis seberapa besar kepercayaan pasien mampu memoderasi pelayanan tenaga administrasi terhadap kepuasan pasien BPJS? 
5. Untuk menganalisis seberapa besar kepercayaan pasien mampu memoderasi kualitas kerja tenaga medis terhadap kepuasan pasien BPJS?

\section{TINJAUAN PUSTAKA}

Pengertian Kepuasan menurut Faezipour dan Ferreira (2013), kepuasan konsumen didefinisikan sebagai seluruh pernyataan (assessment) dari kinerja. Menurut Pohan (2013), faktor-faktor yang mempengaruhi kepuasan pengguna layanan kesehatan bersifat multidimensi dimana dapat ditinjau dari lingkungan fisik, kesinambungan pelayanan, hasil layanan, biaya layanan, hubungan yang terjalin antara penyedia dan penerima layanan, kelengkapan informasi tentang penyakit, perhatian, sistem pelayanan, akses fisik, faktor ekonomi, hingga kompetensi dan konsistensi atas standar pelayanan yang telah ditetapkan. Secara garis besar, terdapat 4 (empat) dimensi yang dapat diukur untuk mengetahui kepuasan pengguna layanan kesehatan, yakni akses layanan, mutu layanan, proses layanan dan sistem pelayanan. Kotler (1994)menyebutkan kepuasan pengguna dapat diukur dengan 4 macam metode pengukuran, yakni: 1)Sistem keluhan dan saran, 2) ghost shopping, 3)lost customer analysis, dan 4) survei kepuasan pengguna.

\section{Pelayanan Tenaga Administrasi dan Kepuasan Pasien}

Pelayanan tenaga administrasi terdiri dari dua bagian pelayanan administrasi dan keuangan, pelayanan administrasi diruma sakit antara lain salah satunya adalah bidang ketatausahaan seperti pendaftaran dan rekam medis, sedangkan bidang keuangan seperti proses pembayaran biaya rawat inap pasien. Pasuraman, Zeithaml dan Berry (Muninjaya, 2014:10) membagi dimensi kualitas pelayanan berdasarkan beberapa aspek komponen. Komponen pelayanan tersebut kemudian dibagi menjadi lima dan dikenal dengan nama ServQual, dimana kelima dimensi menurut
Pasuraman dkk, antara lain: Responsiveness (Daya Tanggap), Reliability(Kehandalan), Assurance (Jaminan), Empathy (Empati), Tangible (Bukti Nyata).Hubungan pelayanan administrasi dengan kepuasan pasien adalah pasien mempunyai pengaruh positif terhadap kepuasan pasien. Semakin baik persepsi konsumen terhadap pelayanan adminitrasi maka kepuasan pasien juga akan semakin tinggi. Dan jika persepsi konsumen buruk terhadap pelayanan administrasi maka kepuasan pasien juga akan semakin rendah. Penelitian yang dilakukan oleh Sulistyo (2016) "Correlation between The Healthcare Quality and The Satisfaction Level of BPJS Patients in Puskesmas Delanggu, Klaten Regency" menyebutkan bahwa variabel pelayanan tenaga administrasi berpengaruh positif dan signifikan terhadap kepuasan pasien BPJS.

H1 = Hubungan Pelayanan Tenaga Administrasi dengan Kepuasan pasien

\section{Kualitas Tenaga Medis dan Kepuasan Pasien}

Tenaga kesehatan khususnya dokter, perawat harus peka dengan keadaan pasien, perawat tidak hanya menangani kondisi fisik dari pasien tetapi kondisi psikisnya juga, dengan berempati terhadap pasien maka diharapkan pasien dapat sembuh lebih cepat. Untuk dapat memiliki kemampuan empati, seorang perawat harus mampu bersosialisasi kepada pasien. Donabedian (1980), mengatakan bahwa tenaga medis merupakan unsur yang memberikan pengaruh paling besar dalam menentukan kualitas dari pelayanan yang diberikan kepada pasien di Rumah Sakit.

Hubungan pelayanan dan kualitas kerja tenaga medis pada kepuasan pasien mempunyai pengaruh positif terhadap kepuasan pasien. Semakin baik persepsi konsumen terhadap pelayanan medis maka kepuasan pasien juga akan semakin tinggi. Dan jika persepsi konsumen terhadap pelayanan medis maka kepuasan pasien 
akan semakin rendah. Penelitian yang dilakukan oleh Khoiri dan Hermastutik (2015). "The Correlation The Quality of Nursing Service And The Satisfaction Of The Patients Holding BPJS Card In Health Service Center" menyatakan bahwa ada hubungan mutu pelayanan terhadap tingkat kepuasan pasien BPJS di Puskesmas Mojowarno Kabupaten Jombang.

H2 = Hubungan antara Kualitas Tenaga Medis dengan Kepuasan Pasien

\section{Kepercayaan Pasien dan Kepuasan Pasien}

Menurut Okky Ervina, (2013). Bahwa kepercayaan merupakan suatu keyakinan di mana salah satu pihak yang terlibat dalam pertukaran memiliki keandalan dan integritas yang dapat memberikan hasil yang positif. Kepercayaan adalah variabel terpenting dalam membangun hubungan jangka panjang antara pihak satu dengan yang lainnya. Yang dapat mempengaruhi tingkat kepuasan konsumen adalah kepercayaan konsumen.

Indikator Kepercayaan : Menurut Mayer et al (2010:2) faktor yang membentukkepercayaan seseorang terhadap yang lain ada tiga, yaitu : Kemampuan (Ability), Kebaikan Hati (Benevolence), Integritas (Integrity)

Terciptanya kepuasan pelanggan dapat memberikan beberapa manfaat, di antaranya hubungan antara perusahaan dan pelanggannya menjadi harmonis. Adanya kualitas pelayanan yang baik dan kepercayaan dari konsumen di dalam suatu perusahaan maka akan menciptakan kepuasan bagi para konsumennya. Indikator pengukurannya yaitu : Kemampuan (Ability), Kebaikan Hati(Benevolence), Integritas (Integrity). Penelitian Adhi et al., (2012) menghasilkan dimensi kualitas pelayanan dan kepercayaan berpengaruh positif dan signifikan terhadap kepuasan

H3 = Hubungan antara Kepercayaan Pasien mempengaruhi terhadap Kepuasan pasien

\section{Moderasi Kepercayaan Terhadap Pelayanan Tenaga Administrasi Ke Kepuasan}

Hasil penelitian dari jurnal terdahulu yang dilakukan oleh Kartikasari et al., (2014) menyatakan bahwa; Pengaruh langsung variabel kualitas layanan terhadap kepercayaan mempunyai nilai estimate sebesar 0,876 dengan arah positif, nilai CR sebesar 7,559 dan probability lebih kecil dari 0,001, sehingga dapat disimpulkan kualitas layanan berpengaruh positif dan signifikan terhadap kepercayaan. Pengaruh positif mempunyai arti semakin tinggi kualitas layanan maka akan meningkatkan kepercayaan pasien.

\section{Moderasi Kepercayaan Terhadap Kualitas Tenaga Medis Ke Kepuasan}

Hasil penelitian dari jurnal terdahulu yang dilakukan Nurhayati, (2016). menyatakan bahwa; Berdasarkan hasil penelitian diketahui bahwa peran tenaga medis Puskesmas Pembantu dalam pemeriksaan dan pengobatan pasien di Puskesmas Pembantu Linggang Amer sudah cukup baik yaitu berdasarkan standar operasional prosedur (SOP) yang berlaku di Puskesmas dengan mengutamakan alur pelayanan yang memberikan kemudahan dan kepastian tahapan pelayanan kepada masyarakat. Berdasarkan penjabaran tersebut, diketahui bahwa peran tenaga medis Puskesmas Pembantu Linggang Amer dalam pemeriksaan dan pengobatan pasien sudah sesuai karena berdasarkan SOP. Dengan Adanya SOP maka mutu pelayanan di Puskesmas Pembantu Linggang Amer dalam pemeriksaan dan pengobatan terjamin. Mutu pelayanan kesehatan adalah menunjuk pada tingkat kesempurnaan pelayanan kesehatan, yang disatu pihak dapat menimbulkan kepuasan dan kepercayaan pada setiap pasien sesuai dengan tingkat kepuasan rata-rata penduduk, serta dipihak lain tata cara 
penyelenggaraannya sesuai dengan kode etik dan standar pelayanan profesi yang telah ditetapkan.

\section{METODE PENELITIAN}

\section{Luaran}

Luaran yang diharapkan dari hasil pelaksanaan program ini adalah meningkatkan pelayanan tenaga administrasi dan kualitas tenaga medis yang kompeten. Pentingnya pelayanan yang baik dari pihak tenaga administrasi serta kualitas tenaga medis yang akan mempengaruhi kepuasan pasien

\section{Teknik Pengumpulan Data dan Analisis Data}

Pengumpulan data menggunakan metode angket. Data dikumpulkan dengan cara menyebar kuisioner/daftar pertanyaan untuk mendapatkan data-data penilaian konsumen tentang pengaruh pelayanan tenaga administrasi, kualitas kerja tenaga medis dan kepuasan pasien BPJS yang dimoderasi oleh kepercayaan pasien yang dirasakan. Jenis data yang dikumpulkan termasuk data primer yang diperoleh dari pasien BPJS. Analisis data yang digunakan adalah analisis regresi.

\section{HASIL DAN PEMBAHASAN}

Dalam penelitian ini menggunakan teknik pengambilan sampel menggunakan probabily sampling dan metode analisis data yang digunakan dalam penelitian ini adalah PLS (Partial Least Square) 3.0. PLS ( Patrial Least Square) digunakan karena tidak didasarkan pada banyak asumsi dan sampel yang digunakan relatif kecil sehingga alat ini cocok digunakan dalam penelitian ini.

\section{Hasil Uji Validitas}

Suatu indikator dinyatakan valid jika mempunyai loading factor diatas 0,5 terhadap konstruk yang dituju, output smartPLS untuk loading factor memberikan hasil sebagai berikut:

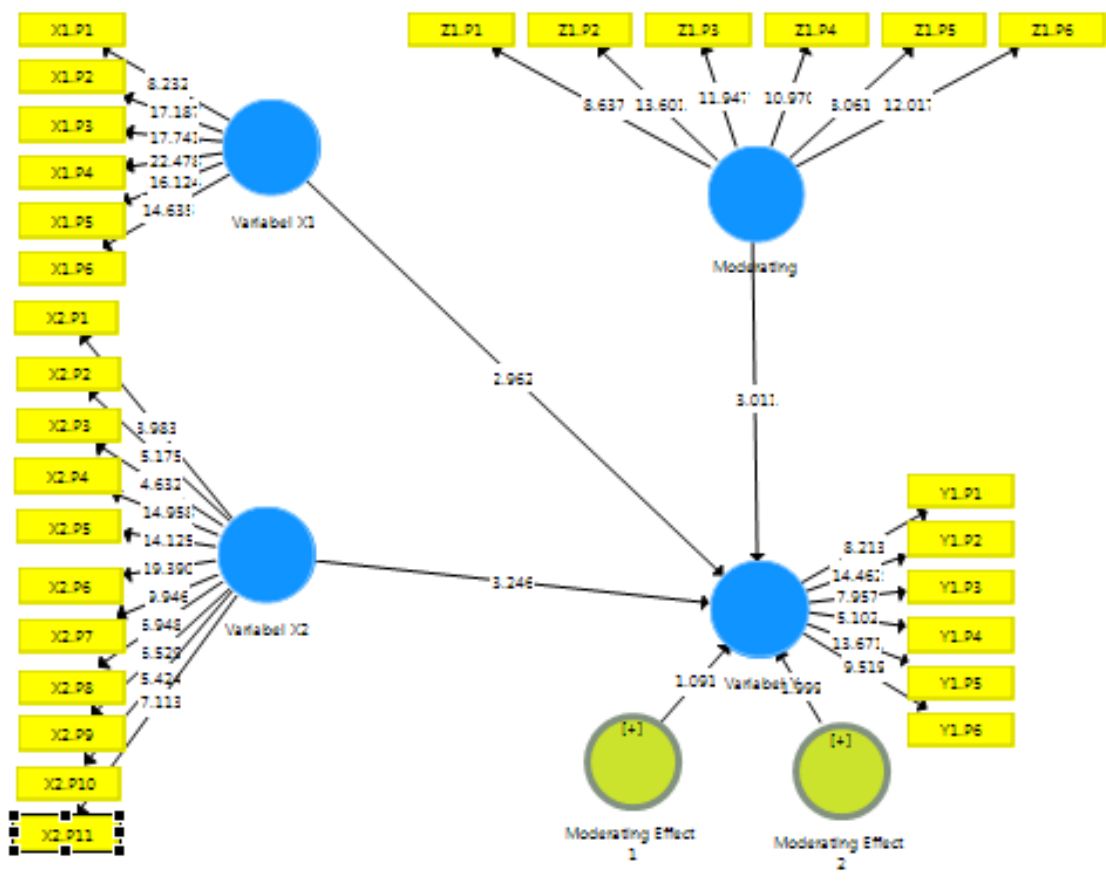

Gambar diatas menunjukkan bahwa loading factor memberikan nilai diatas nilai yang disarankan yaitu sebesar 0,5 . Nilai dibawah 0,5 adalah sebesar 0,487 untuk indikator Y1.P4 kepuasan paseinBPJS. Berarti indikator yang 
dipergunakan dalam penelitian ini adalah valid atau telah memenuhi convergent validity.
Uji reliabilitas juga bisa diperkuat dengan Cronbach's Alpha di mana output SmartPLS memberikan hasil sebagai berikut:

\section{Hasil Uji Reabilitas}

Composite Reliability

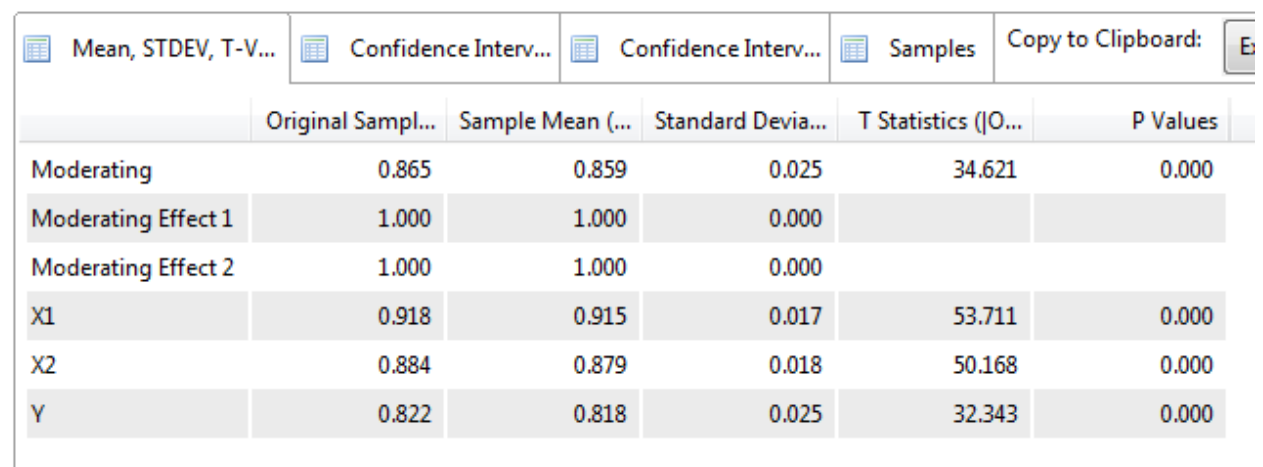

\begin{tabular}{|c|c|c|c|c|c|c|c|c|c|}
\hline \multirow[t]{2}{*}{ E $\mathrm{Me}$} & \multicolumn{2}{|c|}{$\square$ Confidence Interv... } & \multicolumn{2}{|c|}{ (10) Confidence Interv... } & \multicolumn{2}{|c|}{ Samples } & \multicolumn{2}{|c|}{ Copy to Clipboard: } & \multirow{2}{*}{ Ex } \\
\hline & Original Sampl... & \multicolumn{2}{|c|}{ Sample Mean (... } & \multicolumn{2}{|l|}{ Standard Devia... } & \multicolumn{2}{|c|}{ T Statistics (ןo... } & P Values & \\
\hline Moderating & 0.815 & & 0.810 & 0.035 & & & .252 & 0.00 & \\
\hline Moderating Effect 1 & 1.000 & & 1.000 & & & & & & \\
\hline Moderating Effect 2 & 1.000 & & 1.000 & & & & & & \\
\hline $\mathrm{x} 1$ & 0.896 & & 0.895 & 0.022 & & & .645 & 0.00 & \\
\hline $\mathrm{X}_{2}$ & 0.853 & & 0.848 & 0.023 & & & 301 & 0.00 & \\
\hline $\mathbf{Y}$ & 0.741 & & 0.736 & 0.041 & & & 206 & 0.00 & \\
\hline
\end{tabular}

Berdasarkan tabel di atas dapat diketahui bahwa seluruh variabel memiliki nilai yang disarankan adalah di atas 0,7 dan pada tabel di atas menunjukkan bahwa nilai Cronbach's Alpha untuk semua kontruk berada di atas 0,7 sehingga semua variabel dan dimensi penelitian dinyatakan reliabel.

\section{PEMBAHASAN}

Hipotesis Pertama yang dibuat oleh peneliti bahwa "Pengaruh signifikan Pelayanan Tenaga Administrasi terhadap Kepuasan Pasien BPJS". Setelah dilakukan analisis menggunakan PLS didapatkan hasil penelitian yaitu pengaruh signifikan pelayanan tenaga administrasi. Responsiveness (Daya Tanggap), Reliability (Kehandalan), Assurance (Jaminan), Empathy (Empati) Tangible (Bukti Nyata) mempengaruhi terhadap kepuasan pasien BPJS, dimana T-Statistik sebesar 2,962 (> 1,96). Sehingga hipotesis pertama diterima.
Menurut hasil penelitian yang kami lakukan di RS MH Thamrin Jakarta para pasien BPJS merasa puas dengan pelayanan tenaga administrasi di RS tersebut karena pelayanan tenaga administrasi disana sangat baik untuk pengguna BPJS serta tenaga administrasi tersebut sangat cepat tanggap, handal, dan ramah.

Hipotesis Kedua yang dibuat oleh peneliti bahwa "Pengaruh signifikan Kualitas Kerja Tenaga Medis terhadap Kepuasan Pasien BPJS”. Setelah dilakukan analisis menggunakan PLS didapatkan hasil penelitian yaitu pengaruh signifikan kualitas kerja tenaga medis terhadap kepuasan pasien BPJS, dimana T-Statistik sebesar 3,246 (> 1,96). Sehingga hipotesis kedua diterima. Menurut hasil penelitian yang kami lakukan kualitas kerja dari tenaga medis di RS MH Thamrin Jakarta sangat baik karena para tenaga medis disana 
memiliki ketepatan diagnosis, memiliki data riwayat pasien, melakukan koordinasi secara continuitas bagi semua anggota keluarga sehingga para pasien BPJS memiliki persepsi yang baik terhadap pelayanan medis di RS MH Thamrin.

Hipotesis Ketiga yang dibuat oleh peneliti bahwa"Pengaruh Kepercayaan Pasien terhadap Kepuasan Pasien BPJSsignifikan". Setelah dilakukan analisis menggunakan PLS didapatkan hasil penelitian yaitu kepercayaan pasien berpengaruh signifikan terhadap kepuasan pasien BPJS, dimana T-Statistik sebesar 3,011 (> 1,96). Sehingga hipotesis ketiga diterima. Menurut hasil penelitian yang kami lakukanKemampuan (Ability), Kebaikan Hati (Benevolence), Integritas (Integrity) mempengaruhi kepuasan pasien BPJS. Integritas yang dapat memberikan hasil positif dan kemampuan rumah sakit MH. Thamrin Jakarta dalam melayani pasien dengan baik akan dapat membangun suatu kepercayaan pasien.

Hipotesis Keempat yang dibuat oleh peneliti bahwa "Pengaruh Kepercayaan Pasien signifikan memoderasi Pelayanan Tenaga Administrasi terhadap Kepuasan Pasien BPJS". Setelah dilakukan analisis menggunakan PLS didapatkan hasil penelitian yaitukepercayaan pasien tidak signifikan memoderasi pelayanan tenaga administrasi terhadap kepuasan pasien BPJS, dimana T-Statistik sebesar 1,091 (< 1,96) sehingga hipotesis keempat ditolak. Menurut hasil penelitian yang kami lakukan yaitu kepercayaan pasien tidak signifikan memoderasi pelayanan tenaga administrasi terhadap kepuasan pasien dikarenakan pasien tidak hanya melihat dari pelayanan tetapi kualitas kerja yang dimiliki di rumah sakit tersebut. Jika pelayanan yang kurang baik, tidak adanya keramahan akan berdampak pada kepuasan pasien sehingga akan mengurangi kepercayaan pasien pada RS. MH. Thamrin, sebaliknya jika pelayanan yang baik, daya tanggap dan tidak membeda-bedakan pasien akan memberikan kepercayaan sehingga akan tetap berobat pada rumah sakit tersebut.

Hipotesis Kelima yang dibuat oleh peneliti bahwa "Pengaruh Kepercayaan Pasien signifikan memoderasi Kualitas Kerja Tenaga Medis terhadap Kepuasan Pasien BPJS". Setelah dilakukan analisis menggunakan PLS didapatkan hasil penelitian yaitu kepercayaan pasien berpengaruh signifikan memoderasi kualitas kerja tenaga medis terhadap kepuasan pasien BPJS, dimana T-Statistik sebersar 1,999 $(>1,96)$ sehingga hipotesis kelima diterima. Menurut hasil penelitian yang kami lakukankemampuan , kebaikan hati dan integritas serta tenaga medis yang memiliki sifat extrovet (terbuka), maka akan lebih mudah dalam menangani pasien, karena pasien merasa nyaman dengan keberadaannya sehingga akan memberikan kepuasan dan kepercayaan pada pasien dan pasien dapat merekomendasikan pasien lain untuk dapat berobat di rumah sakit MH. Thamrin.

\section{SIMPULAN DAN SARAN}

\section{SIMPULAN}

Kesimpulan dari penelitian ini adalah :

1. Pelayanan Tenaga Administrasi
berpengaruh signifikan terhadap Kepuasan Pasien BPJS

2. Kualitas Kerja Tenaga Medisberpengaruh signifikan terhadap Kepuasan Pasien BPJS

3. Kepercayaan Pasien berpengaruh signifikanterhadap Kepuasan Pasien BPJS

4. Kepercayaan Pasien tidak signifikan memoderasi Pelayanan Tenaga Administrasi terhadap Kepuasan Pasien BPJS

5. Kepercayaan Pasien signifikan memoderasi Kualitas Kerja Tenaga Medis terhadap Kepuasan Pasien BPJS. 


\section{SARAN}

Saranyang dapat peneliti sampaikan untukmeningkatkan kualitas pelayanan adalahsebagai berikut:

1. Pihak Rumah Sakit MH.Thamrin harus tetap berupaya meningkatkan pelayanan tenaga administrasi serta kualitas terhadap pasien karena pelayanan yang baik dan kualitas kerja tenaga medis yang kompeten sangat berpengaruh signifikan terhadap kepuasan pasien sehingga akan menumbuhkan kepercayaan pasien.

2. Pihak Rumah Sakit MH.Thamrin Pelayanan tenaga medis harus mampu memberikan pelayanan yang baik dari indikator kualitas pelayanan, sumber daya manusia, maupun fasilitas rumah sakit karena kepuasan pasien dipengaruhi secara signifikan oleh kualitas pelayanan yang diberikan.

3. Petugas Tenaga Medis diharapkan untuk tetap meningkatkan profesionalitas dan bekerja dengan sepenuh hati sehingga pasien merasa nyaman dan tidak terjadi kesalahpahaman ketika proses pelayanan berlangsung.

4. Bagi peneliti selanjutnya untuk mendukung variabel kepuasan. 


\section{DAFTAR PUSTAKA}

Duta. 2014. Analisis Tingkat

Kepuasan Pasien di

Puskesmas.

www.journal.unhas.ac.id

diakses tanggal 10 Oktober 2014

Ervina, Okky. 2013. The Effect Of Service Quality and Trust od RSUD Dr. Soewondo Kendali Toward Patients Satisfaction. Final Project. Management Department. Faculty of Economics. Semarang State University. JKMP (ISSN. 2338-445X Vol.1, No. 1, Maret 2013, 1-110

Faezipour,M. \& Ferreira, S. (2013). A System Dynamics Perspective of Patient Satisfaction in Healthcare". Procedia Computer Science. 16:148-156

Muninjaya Gde A. A, (2014: 10), Manajemen Kesehatan Edisi 2, Jakarta: EGC

Nurhayati, M. 2016. Peran Tenaga Medis dalam pelayanan kesehatan

masyarakat di puskesmas pembantu linggang Amer kecamatan linggang bigung Kabupaten kutai barat. eJournal llmu Administrasi Negara, 2016, 4 (1) : $2127-2140$

Pohan, I.S. (2013). Jaminan Mutu Layanan Kesehatan. Jakarta: Buku Kedokteran EGC

Sulistyo, P. B.2016. Correlation between The Healthcare Quality and The Satisfaction
Level of BPJS Patients in Puskesmas Delanggu, Klaten Regency.

Mayer, R.C, Davis, J. H, et al $(2010 ; 2)$. An Integratif Model of Organizational Trust, Academy Of Management Review. 30 (3): 709-734.

Widiasih(2014) tentang persepsi masyarakat terhadap pelayanan BPJS di RSI.Kendal.

Adhi et al., (2012) Pengaruh Kualitas Pelayanan dan Kepercayaan terhadap Kepuasaan Pasien

Kotler (1994) Manajemen Pemasaran, edisi 11, Erlangga

Donabedian (1980), Pengaruh Kualitas Tenaga Medis Terhadap Kepuasan Pasien Rumah Sakit.

Khoiri dan Hermastutik (2015). "The Correlation The Quality Of Nursing Service And The Satisfaction Of The Patients Holding BPJS Card In Health Service Center"

Kartikasari, D, Dewanto A et al., (2014) Pengaruh Kualitas Pelayanan Terhadap Kepuasa dan Kepercayaan di Rumah Sakit Bunda Kandangan Surabaya. Magister Manajemen Rumah Sakit Fakultas Kedokteran Universitas Brawijaya. Jurnal Aplikasi Manajemen Vol. 12 No. 3. 